\title{
The Retinol Circulating Complex Releases Hormonal Ligands During Acute Stress Disorders
}

\author{
Yves Ingenbleek* \\ Laboratory of Nutrition, Faculty of Pharmacy, University Louis Pasteur, Strasbourg, France
}

Intensive care workers actively participate in very hot debates aiming at defining the true metabolic, hormonal and nutritional requirements of critically ill patients, the contributory roles played by thyroid and retinoid ligands being largely underestimated. The present article makes up for redressing the balance on behalf of these last hormonal compounds. The retinol circulating complex is transported in the bloodstream in the form of a trimolecular edifice made up of transthyretin (TTR), retinol-binding protein (RBP) and its retinol ligand. TTR reflects the size of the lean body mass $(L B M)$ and is one of the 3 carrier-proteins of thyroid hormones whereas RBP is the sole conveyor of retinol in human plasma. In acute inflammatory disorders, both TTR and RBP analytes experience abrupt cytokine-induced suppressed hepatic synthesis whose amplitude is dependent on the duration and severity of the inflammatory burden. The steep drop in TTR and

OPEN ACCESS

Edited by:

Noriyuki Koibuchi,

Gunma University, Japan

Reviewed by:

Akira Sugawara,

Tohoku University, Japan

Koshi Hashimoto,

Tokyo Medical and Dental University,

Japan

*Correspondence: Yves Ingenbleek ingen@unistra.fr

Specialty section

This article was submitted to

Thyroid Endocrinology,

a section of the journal

Frontiers in Endocrinology

Received: 09 April 2018

Accepted: 06 August 2018

Published: 04 September 2018

Citation:

Ingenbleek Y (2018) The Retinol

Circulating Complex Releases

Hormonal Ligands During Acute

Stress Disorders.

Front. Endocrinol. 9:487.

doi: 10.3389/fendo.2018.00487 RBP plasma values releases thyroxine and retinol ligands in their physiologically active forms, creating free pools estimated to be 10-20 times larger than those described in healthy subjects. The peak endocrine influence is reached on day 4 and the freed ligands undergo instant cellular overconsumption and urinary leakage of unmetabolized fractions. As a result of these transient hyperthyroid and hyperretinoid states, helpful stimulatory and/or inhibitory processes are set in motion, operating as second frontlines fine-tuning the impulses primarily initiated by cytokines. The data explain why preexisting protein malnutrition, as assessed by subnormal LBM and TTR values, impairs the development of appropriate recovery processes in critically ill patients. These findings have survival implications, emphasizing the need for more adapted therapeutic strategies in intensive care units.

Keywords: lean body mass, transthyretin, retinol-binding protein, thyroid function, cytokines, retinoids, stress disorders, immune responses

\section{INTRODUCTION}

TTR is a highly conserved protein mainly found in the choroid plexus [CP] and in the liver in all classes of vertebrates. TTR is synthesized and secreted by the CP in reptiles, birds and mammals whose TTR gene is believed to have been turned on in the CP at the stage of the stem reptiles (1). Synthesis of TTR in the liver occurs much later during organogenesis in all vertebrate species and continues during adulthood in birds, some marsupials and eutherian mammals (2).

TTR was identified in human CSF in 1942 (3) and in human serum in 1956 (4). In humans, TTR is one of the 3 specific binding proteins [BPs] ensuring the transport of thyroid hormones [TH] (5) in addition to albumin and thyroxine-binding globulin [TBG]. TTR is a molecule comprising 4 identical subunits each displaying a sequence of 127 amino acids [AAs] that coalesce noncovalently 
in parenchymal cells to yield a nascent tetramer with a 55 $\mathrm{kDa}$ molecular mass [MM] (6). The 4 subunits form an open channel harboring 2 binding sites for $\mathrm{TH}$ (7). One of the TTR monomers transports a small companion protein displaying an inner cleft in which a single binding site for one molecule of all-trans-retinol is located, hence its name, retinol-binding protein (RBP, $21 \mathrm{kDa})(8)$. Each $\mathrm{RBP}$ molecule may bind a single retinol ligand to form an holo-RBP complex that may undergo further aggregation with TTR within the liver endoplasmic reticulum, yielding a trimolecular retinolcirculating complex [RCC] edifice totaling $76 \mathrm{kDa}$ in $\mathrm{MM}$ (9). In vitamin A-replete subjects, the 3 components remain attached within close stoichiometry 1: 1: 1 in spite of their different biological half-lives [ $\mathrm{T}_{1 / 2}$ of 2 days for TTR (10) vs. half a day for RBP (11)], showing that TTR safeguards holoRBP from premature urinary output and serves as a limiting factor for the delivery of retinoid compounds to target tissues (12). In accordance with specific tissue requirements, holoRBP molecule releases its retinol ligand to peripheral tissues, a process reducing its affinity for TTR (13). The further loss of a terminal arginine AA residue [174 $\mathrm{Da}$ as $\mathrm{MM}$ ] yields an apoRBP derivative (14) that demonstrates a significantly lowered $\mathrm{T}_{1 / 2}$ of approximately $3.5 \mathrm{~h}$ (15). Apo-RBP rapidly crosses the glomerular barrier prior to its disintegration within the renal tubules. Recycling of the resulting AAs is an efficient process, as shown by the barely detectable concentrations of apo-RBP molecules measured in the urinary output of healthy subjects. The main characteristics of TTR, RBP and apo-RBP molecules are shown in Table 1.

Lean body mass $[\mathrm{LBM}]$ results from a composite agglomeration of fat-free tissues [(18), Figure 1] displaying with TTR closely superimposable developmental patterns from birth to old age [(19), Figure 2], making this BP a reliable surrogate tool to assess fluctuations of LBM size in clinical investigations (20). At birth, plasma TTR concentrations increase linearly without sexual difference during infant growth (21). Human puberty is characterized by major hormonal and metabolic alterations leading to significant redistribution of body tissues (22), most notably the muscle mass which is the main component of LBM by weight. As a result of deeper androgenic impregnation, a significantly higher S-shaped elevation of LBM has been recorded in male adolescents compared with the blunt curve documented in teen-aged girls (23). A comparable gender dimorphism is observed during the onset of adolescence for TTR values, which display developmental patterns (19) tightly matching those outlined by LBM (18). In healthy adults, the sex-related differences in plasma TTR and RBP concentrations are maintained in the form of plateau levels

\footnotetext{
Abbreviations: AA(s), Amino acid(s); APR(s), Acute-phase reactant(s); BDNF, Brain-derived neurotrophic factor; $\mathrm{BP}(\mathrm{s})$, Binding - protein(s); C/EBP, Enhancerbinding protein working as transcription factor; CSF, Cerebrospinal fluid; EGF, Epidermal growth factor; IGF, insulin-like growth factor; JAK/STAT, Signal transducer and activator of nuclear transcription; LBM, lean body mass; mRNA, messenger RNA; NGF, Nerve-growth factor; RARE, Retinoid acid response element; RCC, Retinol circulating complex; RQ, Respiratory quotient; STRA6, Protein coding gene stimulated by retinoic acid 6 involved in transport/homeostasis of retinol; TBG, Thyroxine-binding globulin.
}

TABLE 1 | Main physico-chemical and metabolic characteristics of TTR, RBP, and Apo-RBP (Healthy reference man weighing $70 \mathrm{Kg}$ ).

\begin{tabular}{|c|c|c|c|}
\hline Parameter & TTR & RBP & Apo-RBP \\
\hline $\begin{array}{l}\text { Molecular mass } \\
\text { (Daltons) }\end{array}$ & $54,980(6)$ & $21,200(8)$ & $21,026(14)$ \\
\hline Conformation & Tetrameric & Monomeric & Monomeric \\
\hline AA sequence & $4 \times 127(6)$ & $182(8)$ & $181(14)$ \\
\hline Carbohydrate load & Unglycosylated & Unglycosylated & Unglycosylated \\
\hline Normal plasma values & 270-330 mg/L & 50-65 mg /L & - \\
\hline Biological half-life ( 1 1/2) & 2 days (10) & $14 \mathrm{~h} \mathrm{(11)}$ & $3.5 \mathrm{~h} \mathrm{(15)}$ \\
\hline $\begin{array}{l}\text { Plasma value of bound } \\
\text { ligand (B) }\end{array}$ & $80 \mu \mathrm{g} \mathrm{T} 4 / \mathrm{L}$ & $500 \mu \mathrm{g}$ retinol/L & - \\
\hline $\begin{array}{l}\text { Plasma value of free } \\
\text { ligand }(F)\end{array}$ & $2 \mathrm{ng} \mathrm{FT} 4 / \mathrm{L}$ & $1 \mu \mathrm{g} \mathrm{FR/L}$ & - \\
\hline F/B ratio & $1: 4,000$ & $1: 500$ & - \\
\hline $\begin{array}{l}\text { Distribution space of } \\
\text { free ligands }\end{array}$ & $12 \mathrm{~L}(16)$ & $18 \mathrm{~L}(17)$ & - \\
\hline
\end{tabular}

References of original publications are cited in square bracket.

during full sexual maturity (19). Normal TTR plasma values are stabilized around $300-330 \mathrm{mg} / \mathrm{L}$ in males and approximately $250-270 \mathrm{mg} / \mathrm{L}$ in females whereas RBP plasma values manifest a similar sexual difference at approximately 63 and $52 \mathrm{mg} / \mathrm{L}$, respectively. Beginning in the sixties, the muscle mass undergoes downsizing, with a steeper slope in elderly men, accounting for the concomitant decline in $\operatorname{LBM}(18,23)$ and TTR-RBP values (19). The LBM includes the bulk of total body protein stores and may schematically be subdivided into a visceral compartment comprising metabolically active organs characterized by rapid turnover rates (liver, small intestine mucosa, thymoleukocytic tissues) and a structural compartment distinguished by organs manifesting slower metabolic activity (skeletal muscle mass, skin, cartilages, connecting tissues, appendages) (24). Keeping in mind these body composition characteristics, we here report on the roles played by TTR and RBP as reservoirs of ligands released and converted into bioactive derivatives that have survival impact during the acute phase of any inflammatory condition.

\section{TTR and Thyroid Hormones in Inflammatory Disorders}

In a reference man weighing $70 \mathrm{~kg}$ and living under steady state conditions, protein homeostasis is the net result of protein synthesis equaling protein breakdown. The renewal rate of LBM is evaluated at $3 \%$ day $^{-1}$, meaning that approximately $300 \mathrm{~g}$ of protein are lost and regenerated every day (25). In the case of inflammatory disorders, activated leukocytes release a shower of cytokines that act as autocrine, paracrine and endocrine molecules (26). Cytokines govern the overproduction of acute-phase reactants [APRs], which contribute in several ways to defense and repair mechanisms using specific kinetic and functional properties (27). Interleukin-6 [IL-6], interleukin-1 [IL-1] and tumor-necrosis factor ${ }_{\alpha}\left[\mathrm{TNF}_{\alpha}\right]$ are regarded as key mediators of acute and chronic inflammatory processes, and are not expressed under normal circumstances explaining why 


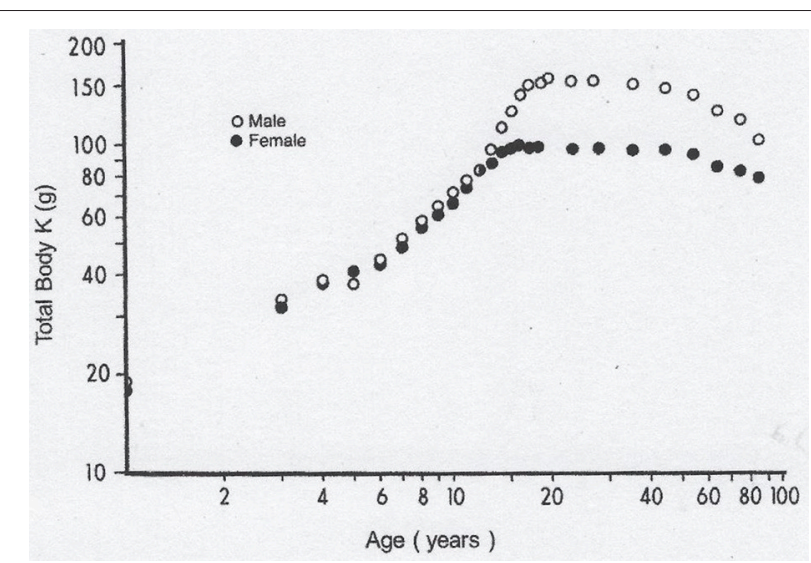

FIGURE 1 | Evolutionary patterns of LBM values throughout the human lifespan. Compilation of 7 different clinical investigations performed in healthy subjects from birth to very old age and showing body accretion TBK values determined by the measuremement of the naturally occuring radioisotope ${ }^{40} \mathrm{~K}$ using dual-energy X-ray absorptiometry (DXA). The results are plotted against age on double-logarithmic coordinates. Ninety-five percent of TBK is sequestered within metabolically active tissues and narrowly correlated with total body N (TBN), making this last parameter a valuable tool to appraise LBM values in health and disease (18). Figure shows that normal TBK concentrations are approximately $140-160 \mathrm{~g}$ in adult men and 90-110 g in adult women.

APR concentrations are maintained at baseline levels (27). IL6-nuclear factor (NF) possesses a high degree of homology with $\mathrm{C} / \mathrm{EBP}-\mathrm{NF}_{1}$, a nuclear transcription factor that function via a retinoic acid response element [RARE] present in its promoter region. C/EBP-NF 1 competes for the same DNA response element of the IL-6 gene, causing a dramatic elevation in APR values under stress conditions (28), together with a reciprocal suppressed TTR synthesis as demonstrated in animal (29) and clinical (30) experiments. The abrupt decline in plasma TTR values has major functional implications, the importance of which has been until now significantly underrated in stress disorders. The liver serves as a large storage site for thyroxine, and is capable of harboring as much as $30 \%$ of the total extrathyroidal $\mathrm{T}_{4}$ body pool (31). The liver also secretes 3 specific BPs that ensure the normal transportation of total thyroxine $\left(\mathrm{TT}_{4}\right)$ into the intravascular space [5L]. Despite minor disagreements, it is generally thought that TBG carries approximately $70 \%$ of $\mathrm{TT}_{4}$ whereas TTR and albumin equally share the carriage of the remaining 30\%. According to the free hormone hypothesis and to the law of mass action (32), any endocrine ligand is metabolically inactive as long as it remains attached to the binding sites of specific carrier protein(s). This applies to $\mathrm{TT}_{4}$ since only minute fractions of its ligand are released in the free form $\left[\mathrm{FT}_{4}\right]$ and may exert hormonal activity (33). The normal $\mathrm{TT}_{4}$ plasma value is $80 \mu \mathrm{g} / \mathrm{L}$, whereas that of $\mathrm{FT}_{4}$ is $20 \mathrm{ng} / \mathrm{L}$, implying a free $[\mathrm{F}]$ to bound $[\mathrm{B}]$ ratio of $1: 4,000$. In the case of acute surgical or inflammatory stress of medium severity, TTR plasma values are usually decreased by $40 \%$ within 4 or 5 days, indicating that the $12 \mu \mathrm{g}$ of thyroxine transported by TTR should release about $5 \mu \mathrm{g}$ of $\mathrm{FT}_{4}$. The first demonstration that the fall in the TTR plasma values is responsible for

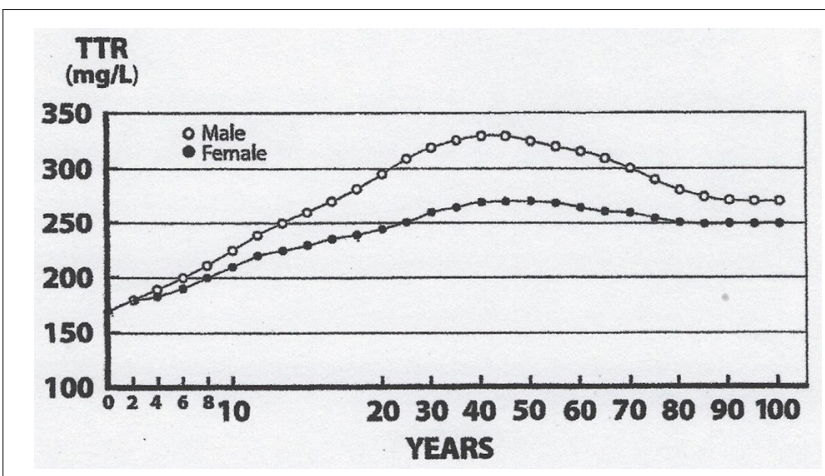

FIGURE 2 | Evolutionary patterns of TTR concentrations throughout the human lifespan. TTR concentration are measured in the blood samples on 67,720 healthy US citizens using immunoturbidimetric analysis (19). TTR and LBM values manifest closely superimposable trajectories: Lowest values measured at birth, linear progression without sexual difference until the onset of puberty, occurrence of sexual dimorphism with more pronounced rise in adult males because of a large musculature, followed by plateau levels until the age of 60y, and finally gradual downsizing toward sacropenia in both sexes with a steeper slope observed in elderly males. Both TTR and LBM curves show comparable abrupt S-shape elevations from the onset of adolescence until the beginning of adulthood, which are here partially obliterated due to changes in the graduation of the abscissa scales.

increased free thyroxinemia in postoperative states was described as early as in 1964 (34), but this original observation was not acknowledged by the scientific community for a long time, mainly because $\mathrm{FT}_{4}$ undergoes instant cellular overconsumption allowing to meet increased metabolic requirements of inflamed tissues.

Freed ligands are now recognized to uniformly diffuse within their normal distribution space of $12 \mathrm{~L}$ (16) to reach an estimated $\mathrm{FT}_{4}$ concentration of $400 \mathrm{ng} / \mathrm{L}$ throughout the critical stress period, meaning about 20 -fold the normal $\mathrm{FT}_{4}$ value. This hormonal alteration thus creates a transient hyperthyroid state that is upheld by the measurement of significantly higher plasma $\mathrm{FT}_{4}$ values in infected $(35)$ and surgical $(36,37)$ patients. At least 3 other stress conditions may contribute to filling the thyroxine distribution space with an additional supply of $\mathrm{FT}_{4}$ ligands: (1) bacterial infections cause a 4-fold accelerated peripheral turnover of both thyroid hormones (38), (2) anesthesia and surgery mobilize $\mathrm{FT}_{4}$ (39) from the large hepatic T4 extrathyroidal reservoir (31), and (3) suppressed synthesis of TBG contributes to the enlargement of the pool of bioavailable $\mathrm{FT}_{4}$ fractions (40). In surgical patients, declining TTR and rising FT4 concentrations demonstrate mirror image of each other (39) with FT4 peak values reached on day 4 after initial impact (36). As a result of $\mathrm{FT}_{4}$ flooding, molecules exceeding body tissue needs remain unmetabolized and undergo renal leakage (41), consistent with the view that increased thyroxinuria faithfully reflects the overall thyroid status (42). This hyperthyroid context has significant functional impact as disclosed by experiments using twodimensional radioautography that indicate that approximatively $8 \%$ of the liver mRNA products are modified under TH influence (43). The biological activity of TH depends on serum hormonal levels, on the roles exerted by at least 3 major cytosolic 
transporters, by intracellular deiodinases and by a large family of nuclear receptors that modulate target gene expression (44). As a result, $\mathrm{TH}$ regulates the basal metabolic rate as well as the activity of enzymes and of most protein and carbohydrate components that participate in the immune adaptive responses to stress disorders (45). Most of these activities are mediated through the activation of transcription factors that have stimulatory influences $(46,47)$ whereas some sustain inhibitory effects as shown by thyroid hormone-induced abrogation of TBG synthesis (40). Several relevant biomarkers produced along this transitory hyperthyroid environment are shown in Table 2 (45, 48-58).

\section{RBP and Retinoid Derivatives in Inflammatory Disorders}

Unlike TTR, holo-RBP is the sole conveyor of retinol in human plasma whose normal concentration in an adult man $(60 \mathrm{mg} / \mathrm{L})$ ensures the carriage of approximately $500 \mu \mathrm{g}$ retinol $/ \mathrm{L}$ whose free fraction (FR) is measured at $1 \mu \mathrm{g} / \mathrm{L}$, hence a normal F:B ratio of 1: 500 . In the case of an acute stress of medium severity that decreases the holo-RBP concentration by $40 \%$, an estimated amount of $200 \mu \mathrm{g}$ retinol is released as FR, diffusing uniformly in a larger distribution space of $18 \mathrm{~L}$ (17) than that of $\mathrm{FT}_{4}$ and yielding an augmented concentration estimated at $10-12 \mu \mathrm{g} / \mathrm{L}$ during the critical illness period, meaning about 10-times the normal free value. To our knowledge, no study has described the sequential upsurge of plasma FR in stress disorders up to now, but clear indirect evidence exists indicating that this adaptive elevation rests on firm grounds since unexpected retinoluria is

TABLE 2 | Stimulatory effects of thyroid hormones in inflammatory disorders.

\begin{tabular}{|c|c|}
\hline $\begin{array}{l}\text { Target mechanisms/ } \\
\text { tissues }\end{array}$ & Induced effects \\
\hline Cellular immunity & $\begin{array}{l}\text { Control of innate and adaptive immune } \\
\text { responses }\end{array}$ \\
\hline T-cell immunity & $\begin{array}{l}\text { Growth and distribution of thymocytes in } \\
\text { lymphoid organs }\end{array}$ \\
\hline Liver injury & $\begin{array}{l}\text { Enhanced mitosis of liver cells following } \\
\text { hepatectomy }\end{array}$ \\
\hline Liver sepsis & $\begin{array}{l}\text { Increased survival of hepatocytes under } \\
\text { stress conditions }\end{array}$ \\
\hline Repair mechanisms & $\begin{array}{l}\text { Boosting effects on hepatic synthesis and } \\
\text { release of IGF-1 }\end{array}$ \\
\hline Erythrocytes & $\begin{array}{l}\text { Stimulatory effects on ferritin synthesis and } \\
\text { hematopoiesis }\end{array}$ \\
\hline Cartilage & $\begin{array}{l}\text { Maturation of chondrocytes promoting } \\
\text { matrix calcification }\end{array}$ \\
\hline Joints & $\begin{array}{l}\text { Differentiation and growth of cartilaginous } \\
\text { tissues }\end{array}$ \\
\hline $\begin{array}{l}\text { Epidermal growth } \\
\text { factor }\end{array}$ & $\begin{array}{l}\text { Binding and phosphorylation of liver EGF } \\
\text { receptors }\end{array}$ \\
\hline Nerve growth factor & Stimulation of NGF mRNA activity \\
\hline Cerebral tissues & $\begin{array}{l}\text { Maturation and differentiation of brain cell } \\
\text { lines }\end{array}$ \\
\hline Brain cell survival & $\begin{array}{l}\text { Upsurge of brain-derived neurotrophic } \\
\text { factor (BDNF) }\end{array}$ \\
\hline
\end{tabular}

References

(45) recovered after surgical stress (41), febrile rotavirus diarrhea (59), shigellosis (60), and enterotoxic Escherichia colitis (61). Healthy subjects do not excrete detectable amounts of retinol, RBP or apo-RBP in the urine, suggesting that their increased urinary values measured following acute stress (41) result from expanded extracellular free pools whose unmetabolized fractions undergo overflow into the kidney. This retinoluria must be regarded as a reflection of the duration and severity of injury that occur transiently and passively without leading to kidney dysfunction. The delivery of retinol targets a variety of cell-surface receptors manifesting uneven distribution in body tissues, with a high concentration found in the epithelial cells of the $\mathrm{CP}$ and organs belonging to the visceral compartment (liver, small intestine, bone marrow) (62). The discovery of a specific cell surface receptor stimulated by retinoic acid 6 [STRA6] that recognizes holo-RBP and mediates the uptake of its retinol ligand (63) has prompted novel investigations involving the JAK/STAT signaling cascade and RBP-dependent insulin resistance pathway $(63,64)$. Interestingly, plasma TTR may block the association of holoRBP with its STRA6 receptor and thereby exert protective effects on RBP-induced insulin resistance $(63,64)$. These data suggest that subnormal TTR plasma values, as seen in protein-depleted states (20), could refrain from interfering with the STRA6mediated retinol uptake process and ensuing events, thereby reinforcing insulin refractoriness. The biological significance of these metabolic peculiarities in morbid conditions such as diabetes, obesity, cancer $(64,65)$ and protein malnutrition $(20)$ needs to be elucidated. In addition, nonspecific intracellular transfer of FR has also been described (66). After crossing the cell membrane, retinol undergoes several conversion steps leading to specific derivatives. Whereas 13-cis-retinal is the required compound that is involved in the visual cycle (67), all-trans-retinoic acid is regarded to be the principal inducer of intracellular effects of vitamin A in mammalian tissues (68). The first study describing nuclear receptors for retinoid compounds (69) has launched an identification of the genomic signaling effects of vitamin $\mathrm{A}$ and a better understanding of the pleiotropic activities exerted at cytosolic level $(68,69)$. Retinoids modulate the differentiation of epithelial $\mathrm{T}$ cells (70), the regulation and maturation of $\mathrm{B}$ cells (71), notably via the stimulation of cytokines (72), T-killer cells (73) and the balance between Th-1 and Th-2 types of T-cells (74). Likewise, $\mathrm{TH}$ and retinoid compounds released in their free form throughout an acute stress reaction manifest a large preponderance of stimulatory activities on effector tissues and may even work in concert with $\mathrm{TH}$ to potentiate immune effects by mediating nuclear mechanisms $(75,76)$. Retinoid compounds may also trigger inhibitory effects by fine-tuning the adequacy of acute phase responses or by depressing the activity of pro-inflammatory mediators such as IL-3 (76), IL12 , and $\mathrm{TNF}_{\alpha}$ (77). Some of the main cellular effects triggered during hyperretinoid states are summarized in Table 3 (70-81), focusing more specific attention on the mechanisms implicated in repairing body tissues injured during stress disorders $(75,76$, $80,81)$.

The above-described clinical example applies to patients afflicted with stress disorders of medium severity. In the case 
TABLE 3 | Stimulatory effects of retinoid compounds in inflammatory disorders.

\begin{tabular}{|c|c|c|}
\hline $\begin{array}{l}\text { Target mechanisms/ } \\
\text { tissues }\end{array}$ & Induced effects & References \\
\hline $\mathrm{T}$ - cell immunity & $\begin{array}{l}\text { Maintenance of T-cells and attenuation of } \\
\text { inflammation }\end{array}$ & (70) \\
\hline B-cell proliferation & $\begin{array}{l}\text { Regulation and differentiation by retinoic } \\
\text { acid }\end{array}$ & (71) \\
\hline Cytokine induction & $\begin{array}{l}\text { Stimulatory overproduction of interleukins } \\
-1 \text { and }-3\end{array}$ & (72) \\
\hline T-cell immunity & Cellular induction via T-killer cell induction & (73) \\
\hline RA-receptors & $\begin{array}{l}\text { Dualistic influences on Th1 and Th2 } \\
\text { development }\end{array}$ & (74) \\
\hline Keratin genes & $\begin{array}{l}\text { Maturation of filament proteins forming } \\
\text { keratin }\end{array}$ & (75) \\
\hline Red blood cells & $\begin{array}{l}\text { Combined effects of TH and RA on } \\
\text { erythropoiesis }\end{array}$ & (76) \\
\hline $\begin{array}{l}\text { RA effects on } \\
\text { leukocytes }\end{array}$ & Antagonistic effects of $\mathrm{Il}_{-10}, \mathrm{II}_{-12}$ and TNF $\alpha$ & (77) \\
\hline Activated B - cells & Promotion of $\mathrm{CD}_{4}(+) \mathrm{T}$ cell differentiation & (78) \\
\hline $\mathrm{CD}_{8} \mathrm{~T}$-cell activation & Modulation of T-cells differentiation by RAs & (79) \\
\hline $\begin{array}{l}\text { Epidermal growth } \\
\text { factor }\end{array}$ & $\begin{array}{l}\text { Control of EGF binding and mitogenic } \\
\text { activities }\end{array}$ & (80) \\
\hline Skin fibroblasts & $\begin{array}{l}\text { Proliferation of extracellular matrix of } \\
\text { dermal fibroblasts }\end{array}$ & (81) \\
\hline
\end{tabular}

of more harmful injuries such as polytrauma, multiple organ failure or burns $(82,83)$, the cytokine-induced fall in the TTRRBP plasma concentrations entails longer slopes in connection with the magnitude and duration of LBM breakdown. The nadir point may be regarded as reflecting the residual LBM reserves below which the adequacy of further inflammatory responses may be compromised. The downward TTR-RBP drop is an obligatory process refractory to any nutritional manipulation. Extensive thermal injury represents one of the most inflicting hypercatabolic states identified by TTR-RBP values falling to about $20-30 \%$ of starting levels with a nadir point reached on days 6-8 after the initial impact (83), implying higher and persisting impregnation of target tissues with freed ligands resulting in super-activated APR responses.

\section{Re-orchestration of Energy and Endocrine Requirements}

The above-mentioned data emphasize that thyroid and retinoid pathways maintain complex interactions and multifaceted cross-talks in stress disorders, operating in combination or antagonistically. Here, it is necessary to take into account the roles played by these freed ligands in the context of other metabolic activities controlled by the so-called counterregulatory hormones. These adaptive responses to stress lead to the dichotomous partitioning of metabolic requirements between healthy and inflamed tissues that are described elsewhere in minute detail (84). The energy requirements of healthy tissues are moving toward lipid dependency $(\mathrm{RQ} \sim 0.7)$, thereby sparing glucose and AA residues (25). Acute stress disorders are followed by a post-impact period of time characterized by the onset of a euthyroid sick syndrome (85) generated by Il- ${ }_{1}$, Il-6 and $\mathrm{TNF} \alpha$ (86-88) which work in concert to negatively affect all functional steps of the hypothalamo-pituitary-thyroid axis, notably via inhibition of $5^{\prime}$ - monodeiodinase activity ( $\left.5^{\prime}-\mathrm{DA}\right)$, thereby hindering intrathyroidal conversion of $\mathrm{FT}_{4}$ to its more potent derivative, $\mathrm{FT}_{3}$. As a result, the drop in plasma $\mathrm{FT}_{3}$ values is accompanied by the maintenance of energy expenditure and protein anabolic processes at the minimally required levels (89).

Inflamed tissues manifest opposite endocrine and metabolic patterns. Ambient hyperglycemia favors the simple diffusion of glucose into the core of injured and poorly irrigated tissues, allowing for the support of the local anabolic drive via anaerobic glycolysis and low oxygen consumption (RQ 1) (25). The liver escapes the overall context of receptor refractoriness and governs the uptake of AAs redirected into the preferential production of defense and repair processes under the control of glucagon and $\mathrm{TNF}_{\alpha}$. Glucocorticoids govern the major acute phase response in liver cells $(27,28)$, as documented for the synthesis of both C-reactive protein (CRP) (90) and $\alpha_{1}$-acid glycoprotein $\left(\alpha_{1}\right.$-AGP) (91), the latter also being under TH-dependency (40). The dichotomous partitioning of energy and substrate requirements is further illustrated by the dualistic behavior of freed IGF1 fractions, the mitogenic processes of which are downregulated in the whole body economy (92) but intensified in injured territories $(93,94)$. Likewise, the aforementioned cytokines operate together to impair intrathyroidal expression and activity of $5^{\prime}$-DA (86-88) and allow the body to meet peripheral tissue requirements in a specific manner that results in a beneficial outcome (95). Taken together, the data show that the $\mathrm{TH}$ ligands released in the free form develop peak endocrine and metabolic effects at the site of inflammation, using specific cytokine mechanisms among which are abrogation of liver synthesis (40), proteolytic breakdown of carrier-proteins $(93,94)$ and enzymatic regulation of intrathyroidal T4 to T3 converting processes (86-88). TTR and RBP clearly play central roles in the dichotomous partitioning and re-orchestration of metabolic priorities associated with the development of adaptive responses to stress disorders.

\section{CONCLUSIONS}

TTR is a plasma protein endowed with a number of functional properties and is now widely used both in developing areas for the nutritional assessment and follow-up of underprivileged populations and in developed countries to identify those hospitalized patients at risk of protein-deficiency. The close links recently established between TTR and LBM developmental patterns in health and disease (20) have renewed interest in the biomarker now regarded as a unique and robust indicator of protein nutritional status. Protein malnutrition is a common finding in hospitalized patients typically characterized by defective cytokine production (96). The amount of ligands released in their free form is determined by the difference between pre- and post-stress TTR-RBP values. The liver 
production of these last carrier-proteins $(12,97)$ undergoes rapid down-regulation in protein-depleted states, explaining why significantly blunted APR responses are recorded when malnutrition coexists with superimposed inflammation (98100). TTR plasma concentrations situated below $200 \mathrm{mg} / \mathrm{L}$ constitute a threshold below which serious clinical complications are predicted to occur (101) whereas a boundary of $100 \mathrm{mg} / \mathrm{L}$ carries ominous prognostic significance (102). We sustain the view that $\mathrm{FT}_{4}$ and $\mathrm{FR}$ fractions released during the acute period of stress should help to throw a fresh look at the overall hormonal climate associated with the rehabilitation of injured patients. Without contesting the validity of the massive increase in $\mathrm{FT}_{4}$ and FR values recorded during the 1970s in critically ill patients, it is nevertheless necessary to keep in mind that comparable data have not been described recently. At the present time, most investigators participate in very hot debates in intensive care units, and aim to stay close to the true metabolic and nutritional requirements of critically ill patients. The scope encompasses energy and protein needs, the roles played by specific AA residues, fatty acid fractions, vitamins and oligonutrients. Hormonal compounds clearly play central roles in

\section{REFERENCES}

1. Achen MG, Duan W, Petterson TM, Harms PJ, Richardson SJ, Lawrence MC, et al. Transthyretin gene expression in choroid plexus first evolved in reptiles. Am J Physiol. (1993) 265:R982-9. doi: 10.1152/ajpregu.1993.265.5.R982

2. Richardson SJ. Evolutionary changes to transthyretin: evolution of transthyretin biosynthesis. FEBS J. (2009) 276:5342-56. doi: 10.1111/j.1742-4658.2009.07244.x

3. Kabat EA, Moore DH, Landow H. An electrophoretic study of the protein components in cerebrospinal fluid and their relationship to serum proteins. J Clin Invest. (1942) 21:571-7. doi: 10.1172/JCI101335

4. Schönenberger $M$, Schultze HE, Schwick G. Uber ein präalbumin des menschlichen serums. Biochem Z. (1956) 328:267-84.

5. Ingbar SH. Pre-albumin: a thyroxine binding-protein of human plasma. Endocrinology (1958) 63:256-9. doi: 10.1210/endo-63-2-256

6. Kanda Y, Goodman DS, Canfield RE, Morgan FJ. The amino acid sequence of human plasma prealbumin. J Biol Chem. (1974) 249:6796-805.

7. Blake CCF, Geisow MJ, Oatley SJ, Rérat B, Rérat C. Structure of prealbumin: secondary, tertiary and quaternary interactions determined by Fourier refinement at 1.8 A. J Mol Biol. (1978) 121:339-56. doi: 10.1016/0022-2836(78)90368-6

8. Kanai M, Raz A, Goodman DS. Retinol-binding protein: the transport protein for vitamin A in human plasma. J Clin Invest. (1968) 47:2025-44. doi: 10.1172/JCI105889

9. Monaco HL. The transthyretin-retinol-binding protein complex. In: Richardson SJ, Cody V, editors. Recent Advances in Transthyretin Evolution, Structure and Biological Functions. Berlin: Springer (2009). p. 123-42. doi: 10.1007/978-3-642-00646-3_8

10. Socolow EL, Woeber KA, Purdy RH, Holloway MT, Ingbar SH. Preparation of $\mathrm{I}^{131}$-labeled human serum prealbumin and its metabolism in normal and sick patients. J Clin Invest. (1965) 44:1600-9. doi: 10.1172/JCI 105266

11. Peterson PA, Nilsson SF, Ostberg L, Rask L, Vahlquist A. Aspects of the metabolism of retinol-binding protein and retinol. Vitam Horm. (1974) 32:181-214. doi: 10.1016/S0083-6729(08)60012-6

12. Ingenbleek Y, Van den Schrieck HG, De Nayer P, De Visscher M. The role of retinol-binding protein in protein-calorie malnutrition. Metabolism (1975) 24:633-41. doi: 10.1016/0026-0495(75)90143-2 this highly controversial issue (103). Authors renowned for having published authoritative monographs on GH (104) and insulin (105) have paved the way for novel and more relevant approaches, as shown by the well-documented detrimental effects generated by the exogenous administration of GH (106) contrasting with the beneficial impact of added insulin which allows normalization of harmful hyperglycemia and attenuation of the levels of cytokines, APRs and most pro-inflammatory biomarkers (107). The under-diagnosed stimulatory or inhibitory activities exerted by $\mathrm{TH}$ and retinoids in stress disorders combining malnutrition and inflammation influences should prompt workers to enlarge the spectrum of more appropriate preventive and therapeutic strategies. This recommendation is founded in the light of recent data showing that increased FT4 values may have deleterious effects on the cardiovascular system (108).

\section{AUTHOR CONTRIBUTIONS}

The author confirms being the sole contributor of this work and approved it for publication.

13. Fex G, Felding P. Factors affecting the concentration of free holo retinolbinding protein in human plasma. Eur J Clin Invest. (1984) 14:146-9. doi: 10.1111/j.1365-2362.1984.tb02104.x

14. Rask L, Vahlquist A, Peterson PA. Studies on two physiological forms of the human retinol-binding protein differing in vitamin $\mathrm{A}$ and arginine content. J Biol Chem. (1971) 246:6638-48.

15. Peterson PA. Demonstration in serum of two physiological forms of the human retinol binding protein. Eur J Clin Invest. (1971) 1:437-44. doi: 10.1111/j.1365-2362.1971.tb00555.x

16. Oppenheimer JH, Bernstein G, Hasen J. Estimation of rapidly exchangeable cellular thyroxine from plasma disappearance curves of simultaneously administered thyroxine- ${ }^{131}$ I and albumin- ${ }^{125}$ I. J Clin Invest. (1967) 46:76277. doi: 10.1172/JCI105577

17. Underwood BA. The determination of vitamin A and some aspects of its distribution, mobilization and transport in health and disease. World Rev Nutr Diet. (1974) 19:123-72. doi: 10.1159/000394767

18. Forbes, GB. Human Body Composition, Growth, Aging, Nutrition, and Activity. Berlin: Springer (1987). 350 p.

19. Bienvenu J, Jeppson JO, Ingenbleek Y. Transthyretin \& retinol-binding protein. In: Ritchie RF, Navolotskaia O, editors. Serum Proteins in Clinical Medicine. FBR. Scarborough: Maine (1996). p. 9.011-8.

20. Ingenbleek Y, Bernstein LH. Plasma transthyretin as a biomarker of lean body mass and catabolic states. Adv Nutr. (2015) 6:572-80. doi: 10.1007/978-3-642-00646-3_20

21. Vahlquist A, Rask L, Peterson PA, Berg T. The concentrations of retinolbinding protein, prealbumin, and transferrin in the sera of newly delivered mothers and children of various ages. Scand J Clin Lab Invest. (1975) 35:569-75. doi: 10.3109/00365517509095782

22. Veldhuis JD, Roemmich JN, Richmond EJ, Rogol AD, Lovejoy JC, SheffieldMoore M, et al. Endocrine control of body composition in infancy, childhood and puberty. Endocr Rev. (2005) 26:114-46. doi: 10.1210/er.2003-0038

23. Gallagher D, Visser M, De Meersman RE, Sepúlveda D, Baumgartner $\mathrm{RN}$, Pierson RN, et al. Appendicular skeletal muscle mass: effects of age, gender and ethnicity. J Appl Physiol. (1997) 83:229-39. doi: 10.1152/jappl.1997.83.1.229

24. Ingenbleek Y, Young VR. Significance of transthyretin in protein metabolism. Clin Chem Lab Med. (2002) 40:1281-91. doi: 10.1515/CCLM.2002.222 
25. Young VR, Fukagawa NK. Energy and protein turnover. In: Kinney JM, Tucker HN, editors. Energy, Metabolism, Tissue Determinants and Cellular Corollaries. New York, NY: Raven Press (1992). p. 439-66.

26. Bienvenu J, Monneret G, Fabien N, Revillard JP. The clinical usefulness of the measurement of cytokines. Clin Chem Lab Med. (2000) 38:267-85. doi: 10.1515/CCLM.2000.040

27. Gabay C, Kushner I. Acute-phase proteins and other systemic responses to inflammation. $N$ Engl J Med. (1999) 340:448-54. doi: 10.1056/NEJM199902113400607

28. Akira S, Hirano T, Taga T, Kishimoto T. Biology of multifunctional cytokines: IL-6 and related molecules (IL-1 and TNF). FASEB J. (1990) 4:2860-67.

29. Murakami T, Ohnishi S, Nishiguchi S, Maeda S, Araki S, Shimada K. Acute-phase response of mRNAs for serum amyloid P component, Creactive protein and prealbumin (transthyretin) in mouse liver. Biochem Biophys Res Commun. (1988) 155:554-60. doi: 10.1016/S0006-291X(88) 80530-8

30. Banks RE, Forbes MA, Storr M, Higginson J, Thompson D, Raynes J, et al. The acute phase protein response in patients receiving subcutaneous IL-6. Clin Exp Immunol. (1995) 102:217-23. doi: 10.1111/j.1365-2249.1995.tb06659.x

31. Cavalieri RR, Searle G. The kinetics of distribution between plasma and liver of ${ }^{131}$ I-labeled L-thyroxine in man: observations of subjects with normal and decreased serum thyroxine-binding globulin. J Clin Invest. (1966) 45:939-49. doi: 10.1172/JCI105409

32. Mendel CM. The free hormone hypothesis: a physiologically based mathematical model. Endocr Rev. (1989) 10:2329-74. doi: 10.1210/edrv-10-3-232

33. Mendel CM, Cavalieri RR, Weisiger RA. Uptake of thyroxine by the perfused rat liver: implications for the free hormone hypothesis. Am J Physiol. (1988) 255:E110-9. doi: 10.1152/ajpendo.1988.255.2.E110

34. Surks MI, Oppenheimer JH. Postoperative changes in the concentration of thyroxine-binding prealbumin and serum free thyroxine. J Clin Endocrinol Metab. (1964) 24:794-802. doi: 10.1210/jcem-24-8-794

35. Talwar KK, Sawhney RC, Rastogi GK. Serum levels of thyrotropin, thyroid hormones and their response to thyrotropin releasing hormone in infective febrile illnesses. J Clin Endocrinol Metab. (1977) 44:398-403. doi: 10.1210/jcem-44-2-398

36. Prescott RW, Yeo PP, Watson MJ, Johnston ID, Ratcliffe JG, Evered DC. Total and free thyroid hormone concentrations after elective surgery. J Clin Pathol. (1979) 32:321-4. doi: 10.1136/jcp.32.4.321

37. Saatvedt K, Lindberg $H$, Geiran OR, Fiane A, Seem E, Michelsen $\mathrm{S}$, et al. Thyroid function during and after cardiopulmonary bypass in children. Acta Anaesthesiol Scand. (1998) 42:1100-03. doi: 10.1111/j.1399-6576.1998.tb05384.x

38. Gregerman RI, Solomon N. Acceleration of thyroxine and triiodothyronine turnover during bacterial pulmonary infections and fever: implications for the functional state of the thyroid during stress and in senescence. J Clin Endocrinol Metab. (1967) 27:93-105. doi: 10.1210/jcem-2 7-1-93

39. Harland WA, Horton PW, Strang R, Fitzgerald B, Richards JR, Holloway KB, et al. Release of thyroxine from the liver during anaesthesia and surgery. $\mathrm{Br} \mathrm{J}$ Anaesth. (1974) 46:818-20. doi: 10.1093/bja/46.11.818

40. Kobayashi M, Horiuchi R, Hachisu T, Takikawa H. Dualistic effects of thyroid hormone on a human hepatoma cell line: inhibition of thyroxinebinding globulin synthesis and stimulation of $\alpha_{1}$-acid glycoprotein synthesis. Endocrinology (1988) 123:631-40. doi: 10.1210/endo-123$1-631$

41. Ramsden DB, Princé HP, Burr WA, Bradwell AR, Black EG, Evans AE, et al. The inter-relationship of thyroid hormones, vitamin A and their binding proteins following acute stress. Clin Endocrinol. (1978) 8:109-22. doi: 10.1111/j.1365-2265.1978.tb02159.x

42. Rogowski P, Sierback-Nielsen K, Hansen JM. Urinary excretion of thyroxine and triiodothyronine in different thyroid function states in man. Acta Endocrinol. (1978) 87:525-34. doi: 10.1530/acta.0.0870525

43. Seelig S, Liaw C, Towle HC, Oppenheimer JH. Thyroid hormone attenuates and augments hepatic gene expression at a pretranslational level. Proc Natl Acad Sci USA. (1981) 78:4733-7. doi: 10.1073/pnas.78.8.4733
44. Mendoza A, Hollenberg AN. New insights into thyroid hormone action. Pharmacol Ther. (2017) 173:135-45. doi: 10.1016/j.pharmthera.2017.02.012

45. De Vito P, Incerpi S, Pedersen JZ, Luly P, Davis FB, Davis PJ. Thyroid hormones as modulators of immune activities at the cellular level. Thyroid (2011) 21:879-90. doi: 10.1089/thy.2010.0429

46. Zhang J, Lazer MA. The mechanism of action of thyroid hormones. Annu Rev Physiol. (2000) 62:439-66. doi: 10.114665/annurev.physiol.62.1.439

47. Mullur R, Liu YY, Brent GA. Thyroid hormone regulation of metabolism. Physiol Rev. (2014) 94:355-82. doi: 10.1152/physrev.000 30.2013

48. Ribeiro-Carvalho MM, Smaniotto S, Neves-Dos-Santos S, Mouço T, Savino W, Mello-Coelho V. Triiodothyronine modulates differential homing of recent thymic emigrants to peripheral lymphoid organs. Scand J Immunol. (2007) 66:8-16. doi: 10.1111/j.1365-3083.2007. 01910.x

49. Oren R, Resnick MB, Brill S, Dotan I, Zaidel L, Lifshits-Mercer B, et al. Thyroxine accelerates proliferation of injured liver cells. J Hepatol. (1998) 29:634-7. doi: 10.1016/S0168-8278(98)80159-1

50. Sukocheva OA, Carpenter DO. Anti-apoptotic effects of 3,5,3'triiodothyronine in mouse hepatocytes. J Endocrinol. (2006) 191:447-58. doi: 10.1677/joe.1.07061

51. Ikeda T, Fujiyama K, Hoshino T, Tanaka Y, Takeuchi T, Mashiba H, et al. Stimulating effect of thyroid hormone on insulin-like growth factor 1 release and synthesis by perfused rat liver. Growth Regul. (1991) 1:39-41.

52. Kubota K, Tamura J, Kurabayashi H, Shirakura T, Kobayashi I. Evaluation of increased serum ferritin levels in patients with hyperthyroidism. Clin Investig. (1993) 72:26-9. doi: 10.1007/BF00231112

53. Alini M, Kofsky Y, Wu W, Pidoux I, Poole AR. In serum-free culture thyroid hormones can induce full expression of chondrocyte hypertrophy leading to matrix calcification. J Bone Miner Res. (1996) 11:105-13. doi: 10.1002/jbmr.5650110115

54. Burch WM, Van Wijk JJ. Triiodothyronine stimulates cartilage growth and maturation by different mechanisms. Am J Physiol. (1987) 252:E176-82. doi: 10.1152/ajpendo.1987.252.2.E176

55. Mukku VR. Regulation of epidermal growth factor receptor levels by thyroid hormone. J Biol Chem. (1984) 259:6443-7.

56. Wion D, Barrand P, Dicou E, Scott J, Brachet P. Serum and thyroid hormones T3 and T4 regulate nerve growth factor mRNA in mouse L cells. FEBS Lett. (1985) 189:37-41. doi: 10.1016/0014-5793(85)80837-1

57. Baas D, Bourbeau D, Sarliève LL, Ittel ME, Dussault JH, Puymirat J. Oligodendrocyte maturation and progenitor cell proliferation are independently regulated by thyroid hormone. Glia (1997) 19:324-32. doi: 10.1002/(SICI)1098-1136 (199704)19:4\%3C324::AID-GLIA5\%3E3.0.CO;2-X

58. Shulga A, Blaesse A, Kysenius K, Huttunen HJ, Tanhuanpää K, Saarma M, et al. Thyroxine regulates BDNF expression to promote survival of injured neurons. Mol Cell Neurosci. (2009) 42:408-18. doi: 10.1016/j.mcn.2009.09.002

59. Alvarez JO, Salazar-Lindo E, Kohatsu J, Miranda P, Stephensen CB. Urinary excretion of retinol in children with acute diarrhea. Am J Clin Nutr. (1995) 61:1273-6. doi: 10.1093/ajcn/61.6.1273

60. Mitra AK, Alvarez JO, Guay-Woodford L, Fuchs GJ, Wahed MA, Stephensen CB. Urinary retinol excretion and kidney function in children with shigellosis. Am J Clin Nutr. (1998) 68:1095-103. doi: 10.1093/ajcn/68. 5.1095

61. Mitra AK, Wahed MA, Chowdhury AK, Stephensen CB. Urinary retinol excretion in children with acute watery diarrhea. J Health Popul Nutr. (2002) 20:12-27.

62. Smeland S, Bjerknes T, Malaba L, Eskild W, Norum KR, Blomhoff R. Tissue distribution of the receptor for plasma retinol-binding protein. Biochem J. (1995) 305:419-24. doi: 10.1042/bj3050419

63. Kawaguchi R, Yu J, Honda J, Hu J, Whitelegge J, Ping P, et al. A membrane receptor for retinol binding protein mediates cellular uptake of vitamin A. Science (2007) 315:820-5. doi: 10.1126/science.1136244

64. Berry DC, Croninger CM, Ghyselinck NB, Noy N. Transthyretin blocks retinol uptake and cell signaling by the holo-retinol-binding protein receptor STRA6. Mol Cell Biol. (2012) 32:3851-9. doi: 10.1128/MCB.00775-12e 
65. Noy N. Vitamin A transport and cell signaling by the retinolbinding protein receptor STRA6. Subcell Biochem. (2016) 81:77-93. doi: 10.1007/978-94-024-0945-1_3

66. Hodam JR, Creek KE. Comparison of the metabolism of retinol delivered to human keratinocytes either bound to serum retinol-binding protein or added directly to the culture medium. Exp Cell Res. (1998) 238:257-64. doi: 10.1006/excr.1997.3857

67. Kiser PD, Golczak M, Palczewski K. Chemistry of the retinoid (visual) cycle. Chem Rev. (2014) 114:194-232. doi: 10.1021\%2Fcr400107q

68. Al Tanoury Z, Piskunov A, Rochette-Egly C. Vitamin A and retinoid signaling: genomic and nongenomic effects. J Lipid Res. (2013) 54:1761-75. doi: 10.1194/jlr.R030833

69. Petkovich M, Brand NJ, Krust A, Chambon P. A human retinoic acid receptor which belongs to the family of nuclear receptors. Nature (1987) 330:444-50. doi: 10.1038/330444a0

70. Ross AC. Vitamin A and retinoic acid in T cell - related immunity. Am J Clin Nutr. (2012) 96:S1166-72. doi: 10.3945/ajcn.112.034637

71. Ertesvåg A, Naderi S, Blomhoff HK. Regulation of B cell proliferation and differentiation by retinoic acid. Semin Immunol. (2009) 21:36-41. doi: 10.1016/j.smim.2008.06.005

72. Trechsel U, Evêquoz V, Fleisch H. Stimulation of interleukin 1 and 3 production by retinoic acid in vitro. Biochem J. (1985) 230:339-44. doi: 10.1042/bj2300339

73. Dennert G, Lotan R. Effects of retinoid acid on the immune system: stimulation of T killer cell induction. Eur J Immunol. (1978) 8:23-9. doi: 10.1002/eji.1830080106

74. Iwata M, Eshima $\mathrm{Y}$, Kagechika H. Retinoic acids exert direct effects on $\mathrm{T}$ cells to suppress Th1 development and enhance Th2 development via retinoic acid receptors. Int Immunol. (2003) 15:1017-25. doi: 10.1093/intimm/dxg101

75. Tomic M, Jiang CK, Epstein HS, Freedberg IM, Samuels HH, Blumenberg M. Nuclear receptors for retinoic acid and thyroid hormone regulate transcription of keratin genes. Cell Regul. (1990) 1:965-73. doi: $10.1091 / \mathrm{mbc} .1 .12 .965$

76. Perrin MC, Blanchet JP, Mouchiroud G. Modulation of human and mouse erythropoiesis by thyroid hormone and retinoic acid: evidence for specific effects at different steps of the erythroid pathway. Hematol Cell Ther. (1997) 39:19-26. doi: 10.1007/s00282-997-0019-2

77. Wang X, Allen C, Ballow M. Retinoic acid enhances the production of IL-10 while reducing the synthesis of IL-12 and TNF-alpha from LPSstimulated monocytes / macrophages. J Clin Immunol. (2007) 27:193-200. doi: 10.1007/s10875-006-9068-5

78. Hall, JA, Cannons JL, Grainger JR, Dos Santos LM, Hand TW, Naik S, et al. Essential role for retinoic acid in the promotion of $\mathrm{CD} 4(+) \mathrm{T}$ cell effector responses via retinoic acid receptor. Immunity (2011) 34:435-47. doi: 10.1016/j.immuni.2011.03.003

79. Allie SR, Zhang W, Tsai CY, Noelle RJ, Usherwood EJ. Critical role for all-trans retinoic acid for optimal effector and effector memory CD8 T cell differenciation. J Immunol. (2013) 190:2178-87. doi: 10.4049/jimmunol.1201945

80. Jetten AM. Effects of retinoic acid on the binding and mitogenic activity of epidermal growth factor. J Cell Physiol. (1982) 110:235-40. doi: $10.1002 /$ jcp. 1041100302

81. Varani J, Mitra RS, Gibbs D, Phan SH, Dixit VM, Mitra R Jr, et al. Alltrans retinoic acid stimulates growth and extracellular matrix production in growth-inhibited cultured human skin fibroblasts. J Invest Dermatol. (1990) 94:717-23. doi: 10.1111/1523-1747.ep12876294

82. Raguso CA, Dupertuis YM, Pichard C. The role of visceral proteins in the nutritional assessment of intensive care unit patients. Curr Opin Clin Nutr Metab Care. (2003) 6:211-6. doi: 10.1097/01.mco.0000058592.27240.95

83. Cynober L, Prugnaud O, Lioret N, Duchemin C, Saizy R, Giboudeau J. Serum transthyretin levels in patients with burn injury. Surgery (1991) 109:640-4.

84. Ingenbleek Y, Bernstein LH. The stressful condition as a nutritionally dependent adaptive dichotomy. Nutrition (1999) 15:305-20. doi: 10.1016/S0899-9007(99)00009-X

85. Wartofsky L, Burman KD. Alterations in thyroid function in patients with systemic illness: the "euthyroid sick syndrome". Endocr Rev. (1982) 3:164217. doi: $10.1210 /$ edrv-3-2-164
86. Dubuis JM, Dayer JM, Siegrist-Kaiser CA, Burger AG. Human recombinant interleukin- $1 \beta$ decreases plasma thyroid hormone and thyroid stimulating hormone levels in rats. Endocrinology (1988) 123:2175-81. doi: 10.1210/endo-123-5-2175

87. Bartalena L, Brogioni S, Grasso L, Velluzzi F, Martino E. Relationship of the increased serum interleukin- 6 concentration to changes of thyroid function in nonthyroidal illness. J Endocrinol Invest. (1994) 17:269-74. doi: $10.1007 / \mathrm{BF} 03348974$

88. Tang KT, Braverman LE, DeVito WJ. Tumor necrosis factor- $\alpha$ and interferon- $\gamma$ modulate gene expression of type I $5^{\prime}$-deiodinase, thyroid peroxidase, and thyroglobulin in FRTL-5 rat thyroid cells. Endocrinology (1995) 136:881-8. doi: 10.1210/endo.136.3. 7867596

89. Ingenbleek Y. Thyroid function in nonthyroid illnesses. In: De Visscher M, editor. The Thyroid Gland. New York, NY: Raven Press (1980). p. 499-527.

90. Depraetere S, Willems J, Joniau M. Stimulation of CRP secretion in HepG2 cells: cooperative effect of dexamethasone and interleukin 6. Agents Actions (1991) 34:369-75. doi: 10.1007/BF01988730

91. Vannice JL, Ringold GM, McLean JW, Taylor JM. Induction of the acute-phase reactant, $\alpha_{1}$-acid glycoprotein, by glucocorticoids in rat hepatoma cells. DNA (1983) 2:205-12. doi: 10.1089/dna.19 83.2.205

92. Ding H, Gao XL, Hirschberg R, Vadgama JV, Kopple JD. Impaired action of insulin- like growth factor 1 on protein synthesis and degradation of skeletal muscle of rats with chronic renal failure. Evidence for a postreceptor defect. J Clin Invest. (1996) 97:1064-75. doi: 10.1172/JCI118499

93. Davenport ML, Isley WL, Pucilowska JB, Pemberton LB, Lyman B, Underwood LE, et al. Insulin-like growth factor-binding protein-3 proteolysis is induced after elective surgery. J Clin Endocrinol Metab. (1992) 75:590-5.

94. Davies SC, Wass JA, Ross RJ, Cotterill AM, Buchanan CR, Coulson VJ, et al. The induction of a specific protease for insulin-like growth factor binding protein-3 in the circulation during severe illness. J Endocrinol. (1991) 130:469-73. doi: 10.1677/joe.0.1300469

95. Langouche L, Vander Perre S, Marques M, Boelen A, Wouters PJ, Casaer MP, et al. Impact of early nutrient restriction during critical illness on the nonthyroidal illness syndrome and its relation with outcome: a randomized, controlled clinical study. J Clin Endocrinol Metab. (2013) 98:1006-13. doi: 10.1210/jc.2012-2809

96. Doherty JF, Golden MH, Remick DG, Griffin GE. Production of interleukin6 and tumour necrosis factor- $\alpha$ in vitro is reduced in whole blood of severely malnourished children. Clin Sci. (1994) 86:347-51. doi: 10.1042/ cs 0860347

97. Ingenbleek Y, De Visscher M, De Nayer P. Measurement of prealbumin as index of protein-calorie malnutrition. Lancet (1972) 7768:106-9. doi: 10.1016/S0140-6736(72)91596-6

98. Doherty JF, Golden MH, Raynes JG, Griffin GE, McAdam KP. Acute-phase response is impaired in severely malnourished children. Clin Sci. (1993) 84:169-75. doi: 10.1042/cs0840169

99. Reid M, Badaloo A, Forrester T, Morlese JF, Heird WC, Jahoor F. The acute-phase protein response to infection in edematous and nonedematous protein-energy malnutrition. Am J Clin Nutr. (2002) 76:1409-15. doi: 10.1093/ajcn/76.6.1409

100. Ibrahim MK, Zambruni M, Melby CL, Melby PC. Impact of childhood malnutrition on host defense and infection. Clin Microbiol Rev. (2017) 30:919-71. doi: 10.1128/CMR.00119-16

101. Rambod M, Kovesdy CP, Bross R, Kopple JD, Kalantar-Zadeh K. Association of serum prealbumin and its changes over time with clinical outcomes and survival in patients receiving hemodialysis. Am J Clin Nutr. (2008) 88:1485-94. doi: 10.3945/ajcn.2008.25906

102. Ho SY, Guo HR, Chen HH, Peng CJ. Nutritional predictors of survival in terminally ill cancer patients. J Formos Med Assoc. (2003) 102:544-50.

103. Preiser JC, van Zanten AR, Berger MM, Biolo G, Casaer MP, Doig GS, et al. Metabolic and nutritional support of critically ill patients: consensus and controversies. Crit Care (2015) 19:35. doi: 10.1186/s13054-0150737-8

104. Harvey S, Scanes CG, Daughaday WH. Growth Hormone: Basic, Clinical and Applied Aspects. Boca Raton, FL: CRC Press (1995). 387 p. 
105. Moller DE, Flier JS. Insulin resistance-mechanisms, syndromes, and implications. $N$ Engl $J$ Med. (1991) 325:938-48. doi: 10.1056/NEJM199109263251307

106. Takala J, Ruokonen E, Webster NR, Nielsen MS, Zandstra DF, Vundelinckx G, et al. Increased mortality associated with growth hormone treatment in critically ill adults. $N$ Engl J Med. (1999) 341:785-92. doi: 10.1056/NEJM199909093411102

107. Van den Berghe G, Wouters P, Weekers F, Verwaest C, Bruyninckx $\mathrm{F}$, Schetz $\mathrm{M}$, et al. Intensive insulin therapy in critically ill patients. N Engl J Med. (2001) 345:1359-67. doi: 10.1056/NEJMoa 011300

108. van Zaane B, Squizzato A, Huijgen R, van Zanten AP, Fliers E, Cannegieter $\mathrm{SC}$, et al. Increasing levels of free thyroxine as a risk factor for a first venous thrombosis: a case-control study. Blood (2010) 115:4344-9. doi: 10.1182\%2Fblood-2009-11-253724

Conflict of Interest Statement: The author declares that the research was conducted in the absence of any commercial or financial relationships that could be construed as a potential conflict of interest.

Copyright (๑) 2018 Ingenbleek. This is an open-access article distributed under the terms of the Creative Commons Attribution License (CC BY). The use, distribution or reproduction in other forums is permitted, provided the original author(s) and the copyright owner(s) are credited and that the original publication in this journal is cited, in accordance with accepted academic practice. No use, distribution or reproduction is permitted which does not comply with these terms. 